\title{
PERCEIVED FACTORS OF SUCCESSFUL SOCIAL ENTERPRISES: THE CASE OF THE STATE ISLAMIC RELIGIOUS COUNCILS AND WAQF LAND DEVELOPMENT IN MALAYSIA
}

\author{
Norinah Mohd Ali ${ }^{1}$ \\ Faculty of Business and Accountancy, University of Malaya, Malaysia \\ Institute of Malaysian and International Studies, \\ National University of Malaysia, Malaysia \\ (Email: nira@ukm.edu.my) \\ Nurul Shahnaz Ahmad Mahdzan ${ }^{2}$ \\ Faculty of Business and Accountancy, \\ University of Malaya, Malaysia \\ (Email: n_shahnaz@um.edu.my) \\ Rubi Ahmad ${ }^{3}$ \\ Faculty of Business and Accountancy, \\ University of Malaya, Malaysia \\ (Email: rubi@um.edu.my) \\ Abdul Rahim Ahmad ${ }^{4}$ \\ Institute of Malaysian and International Studies, \\ National University of Malaysia, Malaysia \\ (Email: ara@ukm.edu.my)
}

Accepted date: $19-06-2019$

Published date: 08-07-2019

To cite this document: Ali, N. M., Mahdzan, N. S. A., Ahmad, R., \& Ahmad, A. R. (2019), Perceived Factors of Successful Social Enterprise: The Case of The Stare Islamic Religious Councils and Waqf Land Development in Malaysia. International Journal of Entrepreneurship and Management Practices, 2(6), 66-75.

DOI: $10.35631 /$ IJEMP.26006

\begin{abstract}
Waqf properties need to be perpetual, irrevocable and inalienable. Even though the social impact is the main objective of waqf creation, it cannot be denied that the economic value is important to help maintain and sustain waqf properties since getting funding for waqf property development is very difficult. Hence, State Islamic Religious Councils (henceforth referred to as the Councils) as waqf trustees are expected to operate like a social enterprise in developing its waqf land. This paper aims to investigate the perceived factors of the current waqf land development practices in each Council that contribute to the Council's success as a social enterprise. This study employs a qualitative approach where semi-structured interviews were conducted with 22 waqf officers from 14 Councils across Malaysia. The result shows that the Councils operate as social enterprises as they are already in pursuit of the dual mission namely financial sustainability and social purpose. There are nine perceived factors of the current waqf land development practices in each Council that contribute to the Council's success as a social enterprise: (1) various types of waqf development; (2) sustainability; (3) opportunity; (4) knowledgeable; (5) financing creativity; (6) monitoring;
\end{abstract}


(7) support; (8) public involvement; and (9) human development. The Councils and its waqf land development practices fit the theoretical aspects of social enterprise since the Councils need to generate enough income from its waqf land development to cover at least the waqf's maintenance cost.

Keywords: Social Enterprise, Waqf Land Development, State Islamic Religious Councils, Malaysia

\section{Introduction}

Waqf is an Islamic endowment, where one party holds a property for the benefits of another and land is one of the major properties that have been donated for waqf. Waqf trustees are expected to develop the waqf land for the benefits of the Muslim society. In Malaysia, there are about 30,888.89 hectares of lands that are being created as waqf (Yayasan Waqaf Malaysia, 2016). These waqf lands are being administered and managed by fourteen State Islamic Religious Councils (henceforth referred to as the Councils), one Council for each state in Malaysia as shown in Table 1. As waqf institutions, the Councils are responsible to develop any waqf land according to the donor's intention as stipulated in the waqf deed or in the Councils' record.

Table 1: Total Waqf Land by State in Malaysia

\begin{tabular}{lc}
\hline State & $\begin{array}{c}\text { Total Waqf } \\
\text { Land }\end{array}$ \\
\hline Johor & 5149.1 \\
\hline Kedah & 820.31 \\
\hline Kelantan & 284.92 \\
\hline Melaka & 357.04 \\
\hline N. Sembilan & 17.18 \\
\hline Pahang & 74.6 \\
\hline Perak & 20225.75 \\
\hline Perlis & 83.22 \\
\hline Pulau Pinang & 742.01 \\
\hline Sabah & 2130.04 \\
\hline Sarawak & 143.68 \\
\hline Selangor & 352.67 \\
\hline Terengganu & 484.1 \\
\hline Federal Territories & 24.27 \\
\hline Total (Malaysia) & $\mathbf{3 0 8 8 8 . 8 9}$ \\
\hline
\end{tabular}

Source: Yayasan Waqaf Malaysia, (2016)

Since waqf properties need to be perpetual, irrevocable and inalienable, the development of waqf land needs to be self-reliant and self-sustaining by which the trustees need to ensure that waqf land can be developed and sustained without relying so much on financing by donors and the government (Mohammad, 2008; Yunus, 2011). Since 2010, waqf land developments have started to be conceptualized in the context of social entrepreneurship and social enterprise where economic value creation is viewed as important as social value creation (Salarzehi et al., 2010; Raimi et al., 2014; Iman \& Mohammad, 2017). Yunus (2011) has emphasized that as a social enterprise, any of its social purpose needs to be self-sustaining and 
able to generate enough income to cover its own cost. Non-profit activity such as waqf land development is also expected to produce some income to sustain the waqf property. Even though the social impact is the main objective of waqf creation, it cannot be denied that the economic value is crucial to help maintain and sustain waqf properties since getting funding for waqf property development is very difficult. The Councils are expected to operate like a social enterprise in developing its waqf land. Since there is a dearth of studies on waqf institution as a social enterprise, this paper aims to investigate the perceived factors of the current waqf land development practices in each Council that contribute to the Council's success as a social enterprise.

\section{Literature Reviews}

Social enterprise can be defined as an organization led by its economic, social, or environmental mission, and uses the private sector business model to gain profit in order to sustain themselves (Barraket et al, 2010; Luke \& Chu, 2013; Muliyaningsih, 2014). According to Muliyaningsih (2014), social entrepreneurs have shown successful effort in tackling social problems using their innovative solutions for welfare, education, health, community development, and the environment. Thus, it can be said that social entrepreneurs and social enterprises aim to create value for the society through the creation of sustainable solutions to neglected societal problems (Zeyen et al., 2013).

The main difference between entrepreneurs operating in purely commercial businesses and social businesses is that the goal and mission of social contribution replace financial gains (Yitshaki et al., 2008). Social entrepreneurs aim to create social value for the public good while commercial entrepreneurs pursue economic value for venture creation (Austin et al., 2012). This is where social enterprise appears as a hybrid organization between the social and the commercial entrepreneurs (Grassl, 2012; Doherty et al., 2014). Social enterprise has emerged as the transformation of non-profit organization from being purely philanthropic to having mixed motives between revenue generation and social responsibility (Kosgaard \& Anderson, 2011). Besides producing economic and social values, Alter (2006) asserts that target population or beneficiary is also one of the theoretical aspects of a social enterprise business model. Alter (2007) had proposed nine feasible business models for social enterprise. Alter's social enterprise business models have illustrated the configurations used to create social and economic value, and can be applied equally to institutions, programs, or service delivery.

According to Ahmed (2011), there is a need to examine the use of waqf to create social enterprises which can give benefits to the public. He emphasizes that the legal status, organizational structure, governance and management, and returns are some of the constraints of waqf institutions to function as social enterprises. Ali et al. (2015) have explained various challenges in developing waqf land such as inefficiency of waqf management by the trustees including providing funding for the development. Even, the income generated from previous waqf land development cannot sustain the maintenance of waqf properties especially for mosque (Shamsiah, 2010). This is where the social enterprise is needed where it can improve the efficiency and effectiveness of the organization by reducing the need for donated funds, providing a diversified funding base or enhancing the quality of social activities (Dees, 1998). Iman and Mohammad (2017) had presenting an overview of waqf and its role in entrepreneurship and proposed a waqf-based entrepreneurship model that can be practiced in Malaysia. However, the studies on waqf institutions as social enterprises and their perceived successful factors as sosial enterprises are still scarce. 


\section{Research Methodology}

The researcher used purposive sampling for data collection. The goal of purposive sampling is to sample cases or participants in a strategic way, so that those sampled are relevant to the research questions that are being posed (Bryman, 2012; Saunders et al., 2012). In Malaysia, The Council is the sole trustee for waqf land development in its respective state. The researcher decided to study the entire population of trustee for waqf land because the size of the population is very small. Malaysia only has 14 Councils and they have been legally appointed by their respective legislations to supervise all waqf assets and be responsible for their management and development in the state. Target respondents are the Head and the officers who are in charge of waqf matters in the Councils. If the Head of waqf unit is not available, the next senior officers will be approached. The respondents can be under the Waqf Department or other departments that handle the waqf land development. The list of the Councils and their corresponding codes is presented in Table 2.

A total of 16 interviews with 22 respondents were conducted with each of the Councils. The interview data were transcribed and analyzed using Atlas.ti version 7. The primary aim of the interview was to obtain information about the perceived factors of the Councils' current waqf land development practices that contribute to the Councils' success as social enterprises.

Table 2. Respondents of The Interview

\begin{tabular}{|c|c|c|c|c|}
\hline No & $\begin{array}{l}\text { State/Federal } \\
\text { Territory }\end{array}$ & The Council & Codes & Respondents Designation \\
\hline 1. & Johor & $\begin{array}{l}\text { Johor Islamic Religious } \\
\text { Council (MAIJ) }\end{array}$ & Council 1 & Assistant Director \\
\hline 2. & Kedah & $\begin{array}{l}\text { State of Kedah Islamic } \\
\text { Religious Council } \\
\text { (MAIK) }\end{array}$ & Council 2 & Admin Officer \\
\hline 3. & Kelantan & $\begin{array}{l}\text { Kelantan Islamic } \\
\text { Religious and Malay } \\
\text { Custom Council (MAIK) }\end{array}$ & Council 3 & Admin Officer \\
\hline 4. & Melaka & $\begin{array}{l}\text { Melaka Islamic Religious } \\
\text { Council (MAIM) }\end{array}$ & Council 4 & $\begin{array}{l}\text { i. Economic Officer } \\
\text { ii. Assistant Deputy } \\
\text { Secretary }\end{array}$ \\
\hline 5. & $\begin{array}{l}\text { Negeri } \\
\text { Sembilan }\end{array}$ & $\begin{array}{l}\text { Negeri Sembilan Islamic } \\
\text { Religious Council } \\
\text { (MAINS) }\end{array}$ & Council 5 & Executive \\
\hline 6. & Pahang & $\begin{array}{l}\text { Pahang Islamic Religious } \\
\text { and Malay Custom } \\
\text { Council (MUIP) }\end{array}$ & Council 6 & $\begin{array}{l}\text { i. Senior Economic Officer } \\
\text { ii. Assistant Economic } \\
\text { Officer }\end{array}$ \\
\hline & Perak & $\begin{array}{l}\text { Perak Islamic Religious } \\
\text { and Malay Custom } \\
\text { Council (MAIPk) }\end{array}$ & Council 7 & $\begin{array}{l}\text { i. Deputy Chief Executive } \\
\text { Officer } \\
\text { ii. Manager }\end{array}$ \\
\hline & Perlis & $\begin{array}{l}\text { Perlis Islamic Religious } \\
\text { and Malay Custom } \\
\text { Council (MAIPs) }\end{array}$ & Council 8 & $\begin{array}{l}\text { i. Head of Waqf Unit } \\
\text { ii. Head of Investment Unit } \\
\text { iii. Acting Chief Executive } \\
\text { Officer }\end{array}$ \\
\hline 9. & Pulau Pinang & State of Penang Islamic & Council 9 & Head of Waqf Unit \\
\hline
\end{tabular}




\begin{tabular}{|c|c|c|c|}
\hline & $\begin{array}{l}\text { Religious Council } \\
\text { (MAIPP) }\end{array}$ & & \\
\hline 10. Sabah & $\begin{array}{l}\text { Sabah Islamic Religious } \\
\text { Council (MUIS) }\end{array}$ & Council 10 & $\begin{array}{l}\text { Head of Waqf and } \\
\text { Baitulmal }\end{array}$ \\
\hline 11. Sarawak & $\begin{array}{l}\text { Sarawak Islamic } \\
\text { Religious Council (MIS) }\end{array}$ & Council 11 & Head of Waqf Division \\
\hline 12. Selangor & $\begin{array}{l}\text { Selangor Islamic } \\
\text { Religious Council } \\
\text { (MAIS) }\end{array}$ & Council 12 & $\begin{array}{l}\text { i. Deputy Chief Executive } \\
\text { Officer } \\
\text { ii. Land Development } \\
\text { Officer }\end{array}$ \\
\hline 13. Terengganu & $\begin{array}{l}\text { Terengganu Islamic } \\
\text { Religious and Malay } \\
\text { Custom Council } \\
\text { (MAIDAM) }\end{array}$ & Council 13 & $\begin{array}{l}\text { i. Deputy Senior Director } \\
\text { ii. Assistant Engineer } \\
\text { iii. Admin Officer }\end{array}$ \\
\hline $\begin{array}{ll}\text { 14. } & \text { Federal } \\
& \text { Territories }\end{array}$ & $\begin{array}{l}\text { Wilayah Persekutuan } \\
\text { Islamic Religious } \\
\text { Council (MAIWP) }\end{array}$ & Council 14 & Assistant Director \\
\hline
\end{tabular}

\section{Results and Discussion}

From the interviews, it is suffice to say that all of the Councils operate as social enterprises when most of the waqf land developments in the states are also moving towards economic value creation. Unlike in the past, majority of the mosques do organized several economic activities to generate income such as community bazaars. This could be the answer to Shamsiah (2010) concerns where she claimed that the waqf revenues can no longer cover the operational costs of waqf properties especially for mosques. In this regard, the Councils are already shown that they are moving from being purely philanthropic to having mixed motives between revenue generation and social responsibility; a characteristics of a social enterprise.

The interviews reveal that there are nine perceived factors of the current waqf land development practices in the states that contribute to the Councils' success as social enterprises as presented in Figure 1.

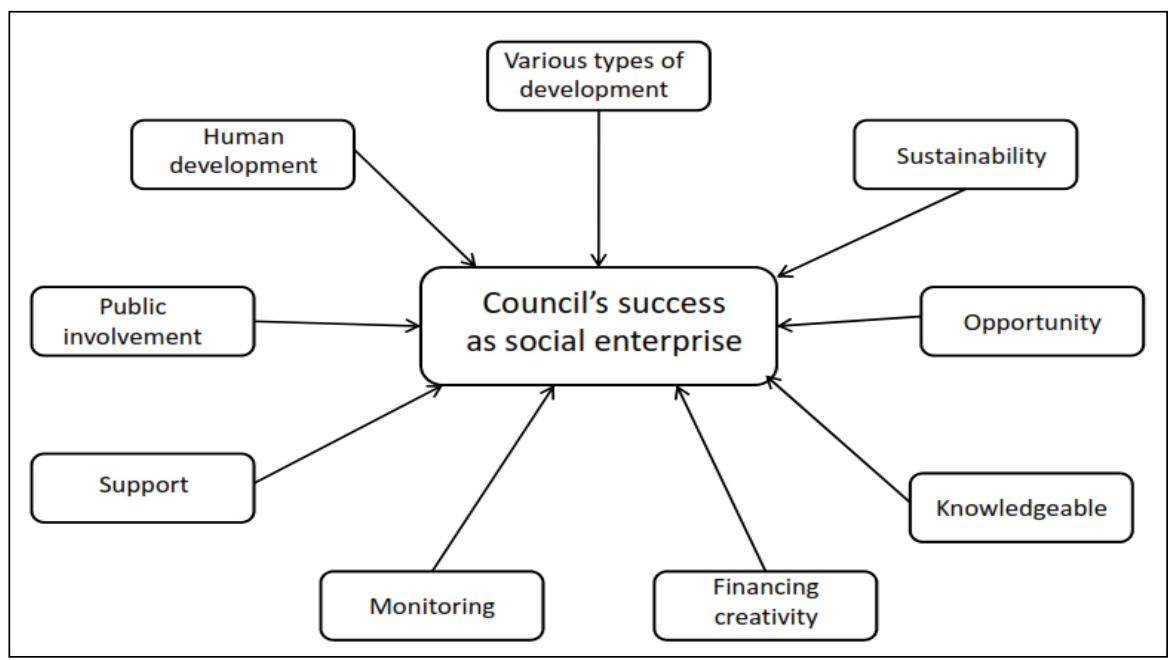

Figure 1: Perceived Factors of the Current Waqf Land Development Practices that Contribute to the Councils' Success as Social Enterprises 
All of the Councils have shown that they do undertake various types of waqf land development either specific or general in their respective state to optimize the benefits to the society. Specific waqf land is a waqf where the donor has declared the purpose of the land in the waqf deed such as for the construction of mosque, cemetery, or orphanage. Meanwhile, for general waqf, the purpose is not mentioned. Thus, the Councils may use the waqf land for any purpose as long as it benefits the public and is not against the Islamic law. Council 2 said that it engages in housing, agriculture and commercial waqf land development. It is also important for the Council to think of new types of development for its waqf, especially the waqf that cannot generate any income. For example, the respondent from Council 2 proposed solar waqf for cemetery land. The respondent from Council 5 said that the Council focuses on both economic and social developments, showing that the Council is already in pursuit of the dual missions namely financial sustainability and social purpose. These thus define the characteristic of social enterprises.

The respondent from Council 2 also viewed the importance of sustainability in waqf land development when he said that economic returns can help develop the rest of the waqf land, especially with regard to social benefits such as health aspect. This is agreed by the respondent from Council 11, where he mentioned that sustainability can be ensured by maintaining specific waqf like mosque using the income received from renting a space adjacent to the mosque for instance, a cafe or a space for book rental. He also mentioned that the public gains a lot from the low rent charged by the mosque. The respondent from Council 11 also added the importance of sustainability and the Council's success by saying:

"Who is going to pay for insurance, electricity, and maintenance if there is no rental income? The waqif (donor) will not pay. So that's why there must be the concept of sustainability. If we do not have sustainability, it means that the waqf property cannot be sustained and will diminish over time. So there is no reward (from Allah SWT), because the waqif only received a reward for the waqf if the property has been used. If we cannot rent it out, the property will obsolete and people will say we are not successful in managing the waqf. But if we were to fix it, where to get the money? So, first of all, we must have that sustainability concept in order to be a good social enterprise." - Council 11

The respondent from Council 6 said, in order to become a successful social enterprise in developing waqf lands, opportunities to secure a business for economic values should not be taken for granted. Council 6 would try to grab any chances that it has to secure a business:

"... if we have an opportunity to buy a petrol station, we will buy. If there is people want to sell supermarket, we will take it. If someone sells a hotel, we will buy it. We grab anything that came because opportunity only came once." Council 6

However, the basis of the decision for acquisition depends on the return on investment (ROI) of the particular acquisition. Council 6 claimed that it is only engaged in new business if the ROI is at least above the interest rate of fixed deposit offered by financial institutions, as the respondent said:

"If the ROI is more than 4\%, we will take the opportunity to invest. Why 4\%? If less than 4\%, we better put our investment in fixed deposit. But for our 
experience, supermarkets can give us ROI of 15 percent, whereas plantation is between 30 to 35 percent. So why don't we invest?" - Council 6

Waqf officers should have the knowledge and skills to run the acquired business that takes place as waqf. It is an advantage when the officer knows how to manage the business, so that he can always know about the business even though it is run by someone else. Waqf officers can hire and learn from an expert if they have little knowledge about the business. This knowledge will become handy if they undertake the same project in the future since they already know how to manage and operate the business.

\begin{abstract}
"When I want to do any project, I need to have a mentor. I have a mentor for my plantation project, - a planter. He teaches me how to manage a plantation. Like hospital and clinic, there is a specialist doctor teaches me how to manage the hospital. Same goes to the hotel so that I know what to do. Like clinic, the doctor teaches me how to open the clinic, so the next round if I am going to open another clinic, I already know how doing it." - Council 6
\end{abstract}

Council 7 and Council 14 said that funding availability is very important before taking any project. Council 9 and Council 11 mentioned that they need to be creative in finding the funds for their waqf land development. One of the example is from the cash collection. Cash collection implies the cash that the Councils receive from the third parties or individuals and comes from various sources such as cash waqf, wakaf kaki(per square feet waqf), salary deduction, waqf fund, waqf share and waqf scheme. The interviews deduce that there are various ways for the Councils to collect cash for waqf land development as presented in Table 3.

Table 3: Cash Collection for Waqf Land Development

\begin{tabular}{|c|c|c|c|}
\hline Council & Collection & Council & Collection \\
\hline 1 & waqf share & 8 & cash waqf \\
\hline 2 & wakaf kaki, waqf fund & 9 & cash waqf \\
\hline 3 & cash waqf & 10 & cash waqf \\
\hline 4 & waqf share & 11 & waqf scheme, salary deduction \\
\hline 5 & cash waqf, salary deduction & 12 & cash waqf \\
\hline 6 & $\begin{array}{c}\text { cash waqf, waqf share, salary } \\
\text { deduction }\end{array}$ & 13 & cash waqf, wakaf kaki \\
\hline 7 & $\begin{array}{c}\text { cash waqf, waqf scheme, waqf } \\
\text { share }\end{array}$ & 14 & waqf fund, cash waqf \\
\hline
\end{tabular}

Council 4, Council 12 and Council 13 suggested to implement istibdal funds to develop waqf land in the states. Istibdal means that any waqf land can be substituted for another property if the land has been acquired by any public authority in accordance with the provisions of any written law, the land does not yield any usufruct or benefit as intended by the donor, or if the use of the land does not comply with the purpose of the waqf (Waqf State of Selangor Enactment 2015). The proceeds from the istibdal can be used to purchase new lands and previous waqf will be transfered to this lands with similar purposes as stipulated by the donor. Council 6 gave examples of how it uses its funding creativity to run waqf businesses annually:

i. It gives an annual grant to selected waqf developments that do not generate any or much income such as in education and health sectors. The annual grant is gained from 
zakat for asnaf category. Council 6 gives this grant to the selected waqf to cover for the operational costs so that it does not have to worry if the income it receives from the waqf itself cannot cover the operational costs. For example, the income from waqf clinic and hemodialysis centre are being used for other things such as to upgrade the existing facilities and for the beneficiaries of the waqf. It charges people who use its waqf facilities lower than the market price such as for dialysis treatment, the market price is RM 250 but the Council only charges it RM 150. With this practice, the financial statement for any waqf business would be no longer negative.

ii. The Council also gives paid-up capital to selected waqf businesses. Paid-up capital means Council 6 gives a certain amount of funds or capital to the businesses and receives shares in return. The said funds may then be utilized for day-to-day operations of the company to pay salary, debts and other expenses. In the practice, plantations, supermarkets and specialist hospital receive paid-up capital through baitulmal fund, whereas waqf hotel, through the federal agency which is the Department of Awqaf, Zakat and Hajj (JAWHAR). All these businesses are run by the Council's own subsidiaries.

Council 1, Council 6, Council 7, Council 9 and Council 11 have agreed that monitoring of the waqf is essential to make sure the objective of the waqf can be achieved. It can be done with sufficient number of staffs administrating the waqf matters in the Council. Council 3 and Council 4 have said that they are facing difficulties to monitor all waqf lands in the state since they do not have enough staff but they need to be proactive in order to make sure the waqf land can be beneficial to the society. Council 13 suggested to pool the waqf resources under one unit or one Ministry as practiced in other countries such as Kuwait and Eqypt in order to ease the burden of the Councils as waqf trustees and at the end the mission of a social enterprise to produce both economic and social values from the waqf land can be achieved.

Council 2, Council 5, Council 9 and Council 14 also said that social enterprises should have good support, either financial or non-financial supports from various authorities. Financial supports can be obtained from the federal government, the state or private parties since they have the financial capacities to finance for waqf land development. The respondents from Council 7 suggested the non-financial support from the Board Members of the Council where they shall consider any waqf land development ideas suggested by younger employees. The respondent from Council 7 further explained that usually younger employees seem to have new and innovative ideas for waqf land development. Support in term of human capital is also mentioned since all fourteen Councils said that they experience a lack of staff especially a permanent staff. Council 4 has many staffs on contract basis and it is hard to train the contract staffs since they are not permanently in the Council. The problem worsens when some Council especially Council 4 only have six staffs in the waqf department to do all the administrative duties related to waqf matters for the entire state. Similar to Council 4, respondent from Council 14 claimed that some of administrative works in Council 14 cannot be done on time due to lack of staff. She added that support in terms of human capital is very important when she said:

"If human capital is not enough, not balance among the departments, no expertise, you give any social enterprise business model, never will ever work." - Council 14 
All of the respondents agreed that identifying the target population is important. This actually fulfilled the theoretical aspects of a social enterprise business model. Since waqf land development involves the relationship between the donor, the trustee as well as the beneficiary, the importance of waqf beneficiary should not be left out when proposing a business model. Council 5 asserted that more public involvement is needed because waqf objective is ultimately concerned about waqf beneficiaries. Waqf land development should involve the targeted population from the very beginning of the development. This includes identifying the needs of the targeted population. The Council added that the awareness of the Council itself or the public can help to make sure that both parties understand what is needed from waqf land development:

"Awareness is important if we want to create any development. Both, the Council and the public need to take part. We need to have more discussion on what is needed for the development." - Council 5

Finanlly, Council 9 considered human development as one of the factors that contribute to the Councils' success as the respondent said:

"We have to have our own philosophy if we want to success. When we developed the waqf land, we have not developed it only for physical, but we are also developing the society. The Muslim community whom are educated with the environment of the waqf development." - Council 9

The respondent of Council 9 highlighted the case of housing waqf land development where the local community is engaged in activities among themselves.

\section{Conclusion}

Nine factors have emerged from the study which contribute to the Councils' success as social enterprises in developing waqf lands in Malaysia. They are: (1) various types of waqf development; (2) sustainability; (3) opportunity; (4) knowledgeable; (5) financing creativity; (6) monitoring; (7) support; (8) public involvement; and (9) human development.

The finding contributes to the literature on social enterprise since there is a lack of studies on social enterprise and waqf activity. The Councils fit the theoretical aspects of social enterprise since the Councils need to generate enough income from its waqf land development to cover at least the waqf's maintenance cost. Since waqf also involves the relationship between the donor and the trustee (The Councils) as well as the beneficiary (target participant), and its resemble Alter's social enterprise business model (Alter, 2007), a future research on social enterprise business model on waqf activity need to be conducted.

\section{References}

Ahmed, H. (2011). Waqf as a sustainable social enterprise: Organisational architecture and prospects. In Fourth World Congress of Muslim Philanthropists, Dubai, March (pp. 23-24).

Ali, N. M., Rahman, M., Ahmad, R. \& Mahdzan, N. S. A. (2015). Necessity of effective and efficient business model for development of waqf lands in Malaysia. Proceeding Muktamar Waqf IQLIMI II. Universiti Sains Malaysia. 351-364.

Alter, K. (2006). Social enterprise models and their mission and money relationships. Social entrepreneurship: New models of sustainable social change, 205-232. 
Alter, K. (2007). Social enterprise typology. Virtue Ventures LLC, 12, 1-124.

Austin, J., Stevenson, H., \& Wei-Skillern, J. (2012). Social and commercial entrepreneurship: same, different, or both? Revista de Administração (São Paulo), 47(3), 370-384.

Barraket, J., Collyer, N., O’Connor, M., \& Anderson, H. (2010). Finding Australia's social enterprise sector: Final report. Brisbane: Queensland University of Technology and Social Traders.

Bryman, A. (2012). Social Research Methods. Fourth edition. Oxford University Press, Oxford.

Dees, J. G. (1998). 'Enterprising Nonprofits', Harvard Business Review, 76(1): 54-67.

Doherty, B., Haugh, H., \& Lyon, F. (2014). Social enterprises as hybrid organizations: A review and research agenda. International Journal of Management Reviews, 16(4), 417-436.

Grassl, W. (2012). Business models of social enterprise: A design approach to hybridity. ACRN Journal of entrepreneurship Perspectives, 1(1), 37-60.

Iman, A. H. M., \& Mohammad, M. T. S. H. (2017). Waqf as a framework for entrepreneurship. Humanomics, 33(4), 419-440.

Korsgaard, S., \& Anderson, A. R. (2011). Enacting entrepreneurship as social value creation. International Small Business Journal, 29(2), 135-151.

Luke, B., \& Chu, V. (2013). Social enterprise versus social entrepreneurship: An examination oof the 'why' and 'how' in pursuing social change. International Small Business Journal, 31(7), pp. 764-784.

Mohammad, M. T. S. (2008). Sustaining the means of sustainability: The need for accepting wakaf (waqf) assets in Malaysian property market.

Muliyaningsih, H. D. (2014). Social entrepreneurship in Islamic social welfare system. International Proceedings of Economics Development and Research, 73, 5.

Raimi, L., Patel, A., \& Adelopo, I. (2014). Corporate social responsibility, Waqf system and Zakat system as faith-based model for poverty reduction. World Journal of Entrepreneurship, Management and Sustainable Development, 10(3), 228-242.

Salarzehi, H., Armesh, H., \& Nikbin, D. (2010). Waqf as a social entrepreneurship model in Islam. International Journal of Business and Management, 5(7), 179.

Saunders, M., Lewis, P. \& Thornhill, A. (2012). Research Methods for Business Students. $6^{\text {th }}$ edition, Pearson Education Limited

Shamsiah Abdul Karim. (2010). Contemporary shari'a compliance structuring for the development and management of waqf assets in Singapore. Kyoto Bulletin of Islamic Area Studies, 3(2), 143-164.

Yayasan Waqaf Malaysia. (2016). Waqf property development transformation master plan study in Malaysia.

Yitshaki, M., Lerner, M., \& Sharir, M. (2008). What are social ventures? Toward a theoretical framework and empirical examination of successful social ventures. Non-market entrepreneurship: Interdisciplinary approaches, 217-241.

Yunus, M. (2011). Building social business: The new kind of capitalism that serves humanity's most pressing needs. Public Affairs.

Zeyen, A., Beckmann, M., Mueller, S., Dees, J. G., Khanin, D., Krueger, N., \& Zacharakis, A. (2013). Social entrepreneurship and broader theories: Shedding new light on the 'Bigger Picture'. Journal of Social Entrepreneurship, 4(1), 88-107. 